\title{
Pre- and Post-Merger Financial Analysis of Banks
}

\author{
Divyesh Khushalani, Manish Sinha* \\ Symbiosis Centre for Management and Human Resource Development, Symbiosis International (Deemed University), \\ Pune, Maharashtra, India
}

Received May 15, 2021; Revised July 3, 2021; Accepted July 28, 2021

\section{Cite This Paper in the following Citation Styles}

(a): [1] Divyesh Khushalani, Manish Sinha , "Pre- and Post-Merger Financial Analysis of Banks," Universal Journal of Accounting and Finance, Vol. 9, No. 6, pp. 1247 - 1257, 2021. DOI: 10.13189/ujaf.2021.090604.

(b): Divyesh Khushalani, Manish Sinha (2021). Pre- and Post-Merger Financial Analysis of Banks. Universal Journal of Accounting and Finance, 9(6), 1247 - 1257. DOI: 10.13189/ujaf.2021.090604.

Copyright $\subseteq 2021$ by authors, all rights reserved. Authors agree that this article remains permanently open access under the terms of the Creative Commons Attribution License 4.0 International License

\begin{abstract}
This work intends to inspect the financial performance of our country's banks before and post the merger. Acquisitions or mergers have been implemented as a tool these days as a respite for distressed banks. By Mergers and Acquisitions, banks are restructured to increase shareholders' value and competitiveness by increasing efficiency. For this work, a specimen of four bank mergers that happened after liberalization was taken and they were analyzed based on financial parameters, for example, Net Profit Margin (NPM), Dividends per Share (DPS), Capital Adequacy Ratio (CAR), Return on Assets (ROA), and Credit Deposit Ratio. This set of parameters chosen is unique when compared to past works. Paired t-test was implemented to identify a substantial change between the financial particulars before and after the merger. The paper also looks at the study's future scope, such as analyzing the stock price movements before and after the merger. This study then can conclude whether the merger of the banks involved was beneficial for the banks and the Indian banking industry or not.
\end{abstract}

Keywords Net Profit Margin (NPM), Dividends per Share (DPS), Capital Adequacy Ratio (CAR), Return on Assets (ROA), Credit Deposit Ratio

\section{Introduction}

For a nation, banks are one of the most important catalysts and occupy a cardinal place in developing the economy of any country. The soundness of the banking structure makes the country's economic development discernible. Economic reforms, liberalization of the market, financial market deregulation have dramatically changed the banking sector, leading to the sophistication of technology and unprecedented competition. Since then, each bank has been relentless in becoming financially strong, well streamlined in operations, and dependable. Banks in our country have made strong headway as financial intermediaries amid the financial crisis that the world is facing. It is pretty clear from the trends in their NPA, profitability, and annual credit production. Enterprise growth can be achieved in two different manners. Some organizations look inward and use their profits to expand in the coming years, which are one of the paths to expand and generally take more diligence and time. However, the more popular path to expand rapidly is to look outward at other organizations. When the enterprise grows by acquiring or merging with another enterprise, inorganic growth occurs. The key aim behind the merger or an acquisition is creating synergy. Organizations get the advantages of cost-effectiveness and higher market share through merging or taking over other entities. Banks have utilized acquisitions or even mergers to achieve higher market portions, larger size, rapid expansion, and harmony to become more contentious economies of scale [1].

India's banking system began in the year 1770 and started with the Bank of Hindustan formation. Later, the Bank of Bombay and the Bank of Calcutta were created by the British-East-India-Company in 1840. In the year 1843 Bank of Madras was created. In 1921, these banks were integrated to form a new entity called the Imperial Bank of India. To develop access to banking facilities into the nation's rural parts, on $1^{\text {st }}$ July 1955 , this bank was partially nationalized and called the State Bank of India (SBI) and its eight affiliate banks (currently seven). State 
Bank of Bikaner and Jaipur was formed from the consolidation of State Bank of Bikaner and Jaipur. In our country, banking can be classified into two phases, the phase before liberalization happened and the phase after it. India's government nationalized fourteen banks on $19^{\text {th }}$ of July 1969 and later added six banks in the phase before liberalization. The new bank of India and Punjab National Bank united in the year 1993 that decreased the count of nationalized banks by one to nineteen. To expand the Banking Sector of our country, the government laid the foundation for liberalization and started issuing licenses to non-public banks. Mergers were suggested for strong public and even for private sector banks by the second Narasimham Committee. There were 46 mergers between 1961 and 1968 and 13 mergers between 1969 and 1992. There were 21 mergers during the period after the reforms from 1993 to the year 2006. Among these 21 mergers, forced mergers accounted for 13 , voluntary mergers accounted for 5, 2 happened due to the firm's confluence into a bank, and the last one happened due to legal obligations. In our country, the banking sector is in a much better shape to handle crises such as 2008-09. The government has implemented several measures to reinforce the financial structure. Backed by various monetary policy changes taken by our RBI, the economic recovery has gained momentum [2].

The Indian government, among others, has taken the path of mergers with a mindset to reform and strengthen the banking structure. To protect the depositor's interests, weaker and even small banks were united with bigger and powerful banks. These mergers can be said to be forceful mergers when some banks show major bad signs, such as big Non-Performing Assets, net-value deterioration, or a severe decrease in the CAR, Reserve Bank of India enforces stay on sick bank operations that comes underneath section 45(1) of the Banking Regulation Act of the year 1949, for some duration. RBI identifies the strong banks in the moratorium period and then asks those banks to prepare a merger scheme. In this consolidation scheme, the bank that acquires the poor bank also takes the poor bank's assets and liabilities and guarantees payment to all account holders should they wish to draw out their claims.

HDFC, ICICI, and Kotak Mahindra have been engaged as an acquiring bank in the last few years in the private space and $\mathrm{SBI}, \mathrm{OBC}$, and $\mathrm{BOB}$ in the government sector [3].

\section{Literature Review}

This work examines the rationale of the banks behind the acquisitions in addition to consolidations. Data was collected for variables such as NPM, ROCE, ROE, ROA, GPM, Debt-Equity Ratio, etc., from the website, Money control and data from BSE, NSE, SEBI, and yearly reports of banks. Two consolidations were chosen for this work: the consolidation of Nedungadi with Punjab National Bank (PNB) and the consolidation of Centurion Bank of Punjab (CBoP) HDFC.T-test were utilized to check the statistical noteworthiness before and post the unification. The work concludes that consolidations ameliorated banks' rendition concerning the reach, efficiency, and dividends as well.

Consolidations are increasingly utilized worldwide to ameliorate the contentiousness of the organizations by expanding into new geographic markets, widening the portfolio, etc.

A specimen of 20 bank consolidations after the liberalization was chosen for this work. Shareholder's return was inspected for the bidder banks, and for that, Wilcoxon sign rank and t-tests were utilized. It was deduced from this work that consolidation deal did not give rise to the mean abnormal return for the acquiring bank [4].

Banks play a vital part in any country's economic growth. Two bank mergers were considered for the study. These were the merger of Bharat Overseas Bank (BhOB) into the Indian Overseas Bank (IOB) that happened in the year 2007 and the union of Centurion Bank of Punjab (CBoP) with HDFC Bank. Data on various financial ratios such as Operating profit margin, return on capital employed (ROCE), Net profit margin, return on equity (ROE), and Debt-Equity ratio was collected before and after the consolidation. Paired t-test was utilized to assess the performance of the banks. It can be concluded that there was a noteworthy change in Operating profit margin, ROCE, NPM, ROE, and Debt-Equity ratio and no noteworthy difference concerning Gross Profit Margin (GPM) for the Indian Overseas Bank. It was also concluded that there was a noteworthy difference concerning GPM for HDFC Bank.

This work is to inspect if there is a noteworthy upswing in the share price or even the bank's financial variables post the consolidation. For example, data for variables, such as ROA, NPM, Return on Long term fund, etc., were collected for six bank consolidations from the Ace-Equity database of Accord-Fintech. IDBI, SBI, and IOB were the three public banks chosen. Similarly, ICICI, Federal, and HDFC were the three non-public banks chosen for this work. In the end, the work deduced that the consolidation was favorable for the banks in general.

Consolidations and even acquisitions are constantly being utilized to make powerful headways in the global environment. They are being utilized to increase the reach as well as clientele. Consolidations or even acquisitions are the ways to remove your challengers from the market. Data was gathered for variables such as NPM, Debt-equity ratio, ROE, GPM, ROCE, etc. $\mathrm{CBoP}$ and HDFC consolidation were chosen. A t-test was utilized to check if there was a noteworthy difference between the variables before and post the consolidation [5]. 
This work attempts to gauge the rendition of the banks prior to and post the consolidation. For this, the consolidation of Nedungadi bank and PNB was chosen. Data for the variables such as the Credit deposit ratio, amount expended on the establishment, advance per employee, investment-deposit ratio, ROA, CAR, NPA, priority sector advance as a percentage of net advances, etc., was gathered from the yearly reports of the banks and ordinary least squares was the method utilized to inspect the rendition. SPSS, MS Excel, and E. views were utilized to work out the data. It was deduced that the amalgamation was certainly lucrative for ameliorating the rendition of the banks.

Consolidations and acquisitions have been utilized to aid the distressed banks, ameliorate the customer base, reach, efficiency, etc., of the acquirer bank. Data was collected for NPM, ROE, GPM, ROA, ROCE, Current-ratio, quick-ratio, etc., for all the consolidations in addition to the acquisitions for the ICICI bank. T-test was utilized to assess the renditions prior to and post the consolidation. Moreover, finally, it was deduced that the consolidations ameliorated the rendition of the bank.

This study examines the consequences of consolidation on the financial parameters of the selected banks. The six consolidations that were selected were between the years of 2004 and 2008. Out of these six consolidations, three were of public banks and the other three of non-public banks. Data was collected for capital sufficiency, quality of assets, liquidity, share prices, etc., from the CMIE database at IIM Bangalore and the banks' yearly reports. The work then concludes that bank mergers or consolidations can help improve consumer base, efficiency, liquidity, gains, etc. However, some of the bad financial symptoms cannot be ameliorated by consolidation alone [6].

This paper uses the CAMEL model to inspect the consequence of mergers on selected non-public banks' financial results in India. It is a ratio model for analyzing banks. Data for 16 ratios were collected before and after the merger. Four bank mergers between the years 2004 and 2008 were selected. The data was collected from the CMIE database at IIM Bangalore. It was concluded that the overall performance improved after the bank's consolidation. Hence, mergers can increase efficiency, market share, and competitiveness by using economies of scale.

Bank consolidation is an event when two or more branches join forces to become one. By these consolidations or even acquisitions, clientele data gets centralized. Big-data analysis techniques can be used for data management. A consequence of the consolidation of education loans was researched under this work. For this work, consolidation of SBI with its five associates was chosen, and analysis-of-variance, logistic-regression, etc., were used. The work deduces that the consolidations aid in increasing the contentiousness as well as clientele [7].

The purpose of the work was to inspect the bank's rendition before and following the consolidation. Some of the variables chosen were NPM, deposits, YOA, business, etc. Data was gathered from the CMIE database, Capitoline-data, yearly reports of banks, articles, and the website more control. Six banks were chosen, of which three were public and the rest non-public. The work then deduced that there was a noteworthy difference in the bank's rendition following the consolidation. The work also tries to understand the course of change and the connection between the bank's physical variables bank. For this motive, analysis-of-variance and multiple-correlations were used.

This paper compares the financial results of the bank prior to and posts the consolidation. Data was collected for financial ratios such as Earnings per Share (EPS), Yield on Advances (YOA), Yield on Investments (YOI), ROA, ROE, Net Profit Ratio (NPR), Profit gained by each Employee and Business that the organization gets for each employee, for five years prior to and post the consolidation. Five banks, namely IDBI Bank, IOB, OBC, $\mathrm{BOB}$, and SBI, were chosen. It was concluded that ROE, ROA, NPR, YOA, and YOE were negatively impacted after the merger. The variables EPS, Profit gained by each employee, and Business that the organization gets for each employee showed an optimistic impact. It was also concluded that Equity, Investments, assets, and advances increase for all banks. However, there is a reduction in their respective yields due to underutilization [8].

This work attempts to scrutinize the banks' rendition for liquidity and profitability prior to and post the unification. For this, CAMEL methodology was utilized. A specimen of seventeen banks starting from the year 1998 to 2016 was chosen for this work. Variables selected were ROE, NPM, ROA, Cost-to-income, etc. It was deduced that the rendition of $\mathrm{BOB}, \mathrm{HDFC}$, and even Federal bank ameliorated post the amalgamation.

This work examines the consequence of consolidation and the acquisition events on the acquirer organizations' share prices. This work took the specimen of 428 such occurrences from the year 2008 to the year 2015. Data for share prices were collected eight days prior and eight days after the consolidation deal from NSE. The research deduced that there were no unusual gains due to the declaration of the consolidation deal.

Merger announcement is a part of the firm's corporate actions. This research paper's grounds were to access the consequence of merger announcement on the share price movements before and after the merger. Data for share prices were collected seven days prior and seven days post the announcement of the merger. Bank mergers from the year 2010 to 2018 were selected. It included the merger of two private banks and two government banks. Zero premises stated that there was no noteworthy influence of the consolidation announcement on the bidder's closing stock price or acquiring bank. Another premise stated that there was a noteworthy influence of the consolidation announcement on the bidder's closing stock price or 
acquiring bank. It was concluded that there was no noteworthy impact of the merger announcement on the share price changes before and after the consolidation declaration [9].

\section{Research Methodology}

This work has been collected from the acquisitions and consolidations/mergers in our country's banking sector. Mergers and Acquisitions chosen for this study have been very important in shaping India's banking sector. Historical importance for choosing these M\&As is given in section 3.2 of this study. Financial and accounting data were collected from the website Money control in addition to the yearly financial reports of banks. Five parameters, such as DPS, NPM, ROA, CAR, and Credit Deposit Ratio, were selected to assess the bank's performance before and after the merger. Justification for selection of these parameters is given in the section 3.1 of this study. Data was collected for five years before the merger and for five years after the merger. Paired t-test was utilized to examine the financial position of the concerned institute before and after the consolidation. Paired/Dependent sample t-test is a statistical method used to decide if the mean change between two sets of observations is zero. This test is a powerful tool to check the change in observations before and after the consolidation. SPSS Statistics was used to perform the paired t-test (significance level, $\alpha=0.05$ ). This methodology is quite similar to the previous works. However, the set of parameters chosen is what makes this work unique [10].

\subsection{Parameters}

A decrease in Dividend per Share (DPS) may indicate that the organization may be in poor financial conditions. NPM is a crucial parameter that can be used to assess the financial well-being of the organization. Through ROA, investors get information about the firm's effectiveness in turning the finances it invests into aggregate income. A bank with greater CAR is highly likely to handle its financial issues and is considered safe. A very low Credit Deposit Ratio suggests that banks are not utilizing their resources to the fullest. If the value reaches above a specific point, it implies a burden on its assets [11].

Hence, these parameters depict the financial state/well-being of the bank. They were selected to inspect the financial situation of the bank before and after the consolidation. They are defined as follows:

- DPS: DPS is the cumulative dividends distributed by a company attributable to each outstanding common share. DPS is calculated by subtracting the special dividends from total dividends paid out over a period divided by outstanding shares.

- NPM: The percentage of income left after all operating costs, interest, and taxes, and preferred stock dividends (but not common stock dividends) is deducted from the overall income of an organization.

- ROA: It is the fraction of the aggregate income of the company to the aggregate assets.

- CAR: It is the fraction of capital of the bank to the risk-adjusted/weighted assets.

- Credit Deposit Ratio: This is the percentage of how much a bank loans out of its mobilized deposits.

\subsection{Selection of Bank Mergers for the Study}

Table 1 shows the list of bank mergers assessed in this study based on the above-mentioned parameters.

Table 1. List of the chosen amalgamations

\begin{tabular}{|r|l|l|c|}
\hline Sr. No. & Acquirer Bank & Acquired Bank & Year \\
\hline 1 & Indian Overseas Bank & Bharat Overseas Bank & 2007 \\
\hline 2 & HDFC Bank & Centurion Bank of Punjab & 2008 \\
\hline 3 & ICICI Bank & Bank of Rajasthan Ltd. & 2010 \\
\hline 4 & Kotak Mahindra Bank & ING Vyasa Bank & 2014 \\
\hline
\end{tabular}

BhOB was a non-public bank headquartered in the city of Chennai. It consolidated with IOB in 2007 that collected all the assets, deposits, and employees. BhOB was founded in the year 1973 to take over from the Indian Overseas Bank's Bangkok branch. It was amongst the few non-public banks allowed by RBI to have a branch overseas and was the sole bank of our country serving Thailand. It was held by seven banks (initial ownership estimates in parentheses): IOB (30 percent), Bank of Rajasthan (BOR) (16 percent), ING Vysya Bank (14.66 percent), Karur Vysya Bank (10 percent), Federal Bank (19.67 percent), South Indian Bank (10 percent), and Karnataka Bank (8.67 percent). Bank of Rajasthan (2519999 shares), ING Vysya Bank (2309999 shares), South Indian Bank (1574999 shares), and the Karnataka Bank (1364999 shares) sold their aggregate of 49.33 percent stake in Bharat Overseas Bank to Indian Overseas Bank at a value of 155 Rs per stock totaling to Rs 120.43 crores. The banks held one share of Bharat Overseas Bank, each as a symbolic shareholding. Karur Vysya Bank and Federal Bank also sold their shares to Indian Overseas Bank. Since 2004, the profitability of Bharat Overseas Bank was under pressure. Hence its merger with a bigger bank was imminent.

RBI formally sanctioned the process for legal and regulatory approval of the $\mathrm{CBoP}$ merger with HDFC Bank on $23^{\text {rd }}$ May 2008. The merger price was Rs 9510 crores. Hence, this was considered one of the largest mergers in domestic banking, the second merger for HDFC Bank after Times Bank's takeover on the 26th February 2000. The merger improved the distribution network of HDFC in both the northern and southern regions. In the northern part of our country, $\mathrm{CBoP}$ was present in nearly 170 locations and some 140 locations in our country's southern part. In the Indian states of Kerala as well as Punjab, CBoP had a concentrated presence. The merged company 
then had a total of 1148 branches in the network at that time. HDFC Bank also took over a powerful small and medium enterprise holding from CBoP. HDFC Bank and CBoP customers did not overlap much before the merger. Against $29 \mathrm{CBoP}$ shares, CBoP's stockholders received a single share of HDFC Bank. HDFC Bank benefited from the merger by expanding the geographic scope of the bank, clientele and branch network, and a greater pool of skilled labor [12].

In 2010, Bank of Rajasthan Ltd. got into trouble when RBI slapped a fine of Rs 25 lakh to violate a multitude of norms such as misrepresentation of documents and irregularities in transactions. An agreement for amalgamation was reached between BOR and ICICI Bank, with the consolidation in effect from $13^{\text {th }}$ August 2010. Bank of Rajasthan shareholders received 25 ICICI shares for every 100, and 18 shares held. The price per branch was around Rs 6.5 crores. The merger increased the combined branch network to over 2500 across the nation, the third merger of the decade for ICICI after acquiring the Bank of Madurai Ltd. in 2001 and Sangli Bank in 2007.

The board members of Kotak Mahindra Bank and even Vysya Bank expressed their desire to merge their respective entities on $20^{\text {th }}$ November 2014. RBI approved this transaction on 31 st March 2015, with effect from $1^{\text {st }}$ April 2015. At the point of the consolidation announcement, ING was the biggest shareholder in Vysya with a 42.7 percent shareholding. According to the terms of the transaction as announced on 20th November 2014, Vysya shareholders had got 0.725 Kotak shares for a single share of Vysya. ING held a 6.5 percent stake in the joint venture operating underneath the umbrella of Kotak's name. ING's stake in the Merged Firm was subjected to a one-year lock-up period from the transaction's end. Based on the book value of Vysya as of 31st December 2014, the benefit for this transaction was around EUR 450 million. Much of this was expressed in the second quarter of 2015 net income. The rise in net income relative to the previously reported net profit of EUR 150 million resulted from the increase in Kotak's share price since the deal was completed and the positive effect on the currency. ING Vysya Bank Ltd. has ceased to exist as of today [13].

\subsection{Hypothesis}

$\mathrm{H}_{0}$ (Null Hypothesis) : There is no major discernible change in the financial parameter before and after the bank's consolidation.

$\mathrm{H}_{1}$ (Alternative Hypothesis): There is a major discernible change in the financial parameter before and after the bank's consolidation.

\section{Results and Analysis}

\subsection{IOB}

Table 2. Variables IOB

\begin{tabular}{|l|c|c|c|c|c|c|c|c|c|c|c|}
\hline Parameters & \multicolumn{7}{|l}{ Pre Merger Years } & \multicolumn{3}{l|}{$\begin{array}{l}\text { Year of } \\
\text { Merger }\end{array}$} & \multicolumn{2}{l}{ Post Merger Years } \\
\hline & 2002 & 2003 & 2004 & 2005 & 2006 & 2007 & 2008 & 2009 & 2010 & 2011 & 2012 \\
\hline $\begin{array}{l}\text { Dividend Per } \\
\text { Share }\end{array}$ & 1.20 & 1.60 & 2.00 & 2.40 & 2.60 & 3.00 & 3.50 & 4.50 & 3.50 & 5.00 & 4.50 \\
\hline $\begin{array}{l}\text { Net Profit } \\
\text { Margin }\end{array}$ & 6.27 & 10.61 & 11.50 & 14.49 & 16.68 & 16.58 & 14.38 & 12.15 & 6.25 & 8.86 & 5.87 \\
\hline $\begin{array}{l}\text { Return on Assets } \\
\text { Including } \\
\text { Revaluations }\end{array}$ & 25.46 & 32.81 & 38.20 & 47.27 & 58.32 & 73.24 & 89.15 & 131.26 & 138.12 & 150.71 & 149.66 \\
\hline $\begin{array}{l}\text { Capital } \\
\text { Adequacy Ratio } \\
\text { (CAR) }\end{array}$ & 10.82 & 11.30 & 12.49 & 14.21 & 13.04 & 13.27 & 11.96 & 12.70 & 14.26 & 14.55 & 13.32 \\
\hline $\begin{array}{l}\text { Credit Deposit } \\
\text { Ratio }\end{array}$ & 47.71 & 47.60 & 48.27 & 53.08 & 63.27 & 68.60 & 70.22 & 73.36 & 72.96 & 74.54 & 78.03 \\
\hline
\end{tabular}


Table 2 shows the key financial variables of the IOB before and following the consolidation:

Table 3. Outcome IOB

\begin{tabular}{|l|l|c|c|c|}
\hline Parameters & Merger & Mean & Std. Dev. & t-value \\
\hline \multirow{2}{*}{ Dividend Per Share } & Pre & 1.960 & 0.573 & \multirow{2}{*}{-9.025} \\
\cline { 2 - 5 } & Post & 4.200 & 0.671 & \\
\hline \multirow{2}{*}{ Net Profit Margin } & Pre & 11.910 & 3.971 & \multirow{2}{*}{0.734} \\
\cline { 2 - 5 } & Post & 9.502 & 3.708 & \\
\hline $\begin{array}{l}\text { Return on Assets } \\
\text { Including Revaluations }\end{array}$ & Pre & 40.412 & 12.786 & \multirow{2}{*}{-12.700} \\
\cline { 2 - 5 } $\begin{array}{l}\text { Capital Adequacy } \\
\text { Ratio (CAR) }\end{array}$ & Pre & 131.780 & 25.178 & \\
\cline { 2 - 5 } & Post & 13.372 & 1.360 & \multirow{2}{*}{-3.357} \\
\hline \multirow{2}{*}{ Credit Deposit Ratio } & Pre & 51.986 & 6.706 & \multirow{2}{*}{-11.336} \\
\cline { 2 - 4 } & Post & 73.822 & 2.835 & \\
\hline
\end{tabular}

Table 3 shows the outcome of the paired t-test that was utilized to assess the bank's performance.
Dividend Per Share (DPS) increased from 1.96 to 4.2. The change was significant, as shown by a $t$-value of -9.025 and a significance value of 0.001 . Hence null hypothesis $\mathrm{H}_{0}$ was rejected. NPM plummeted to 9.502 from 11.91, but the change was not significant. As indicated by a t-value of .734 and a significance value of 0.504 , null hypothesis $\mathrm{H}_{0}$ was not rejected. Return on Assets (including revaluations) also increased, as shown by a $t$-value of -12.7 and a significance value of 0.00 . Capital Adequacy Ratio (CAR) also increased from 12.372 to 13.358 as indicated by a t-value of -3.357 and a significance value of 0.028 . Similarly, Credit Deposit Ratio increased from 51.986 to 73.822 , shown by the t-value of -11.336 and significance value of 0.00 [14].

\subsection{HDFC Bank}

Table 4 shows the key financial variables of the HDFC before and after the consolidation.

Table 4. Variables HDFC

\begin{tabular}{|l|c|c|c|c|c|c|c|c|c|c|c|}
\hline Parameters & \multicolumn{5}{|c|}{ Pre Merger Years } & $\begin{array}{l}\text { Year } \\
\text { of } \\
\text { Merger }\end{array}$ & \multicolumn{5}{c|}{ Post Merger Years } \\
\hline & 2003 & 2004 & 2005 & 2006 & 2007 & 2008 & 2009 & 2010 & 2011 & 2012 & 2013 \\
\hline $\begin{array}{l}\text { Dividend Per } \\
\text { Share }\end{array}$ & 3.00 & 3.50 & 4.50 & 5.50 & 7.00 & 8.50 & 10.00 & 12.00 & 16.50 & 4.30 & 5.50 \\
\hline $\begin{array}{l}\text { Net Profit } \\
\text { Margin }\end{array}$ & 15.87 & 17.15 & 17.87 & 15.63 & 13.74 & 12.87 & 11.35 & 14.77 & 19.70 & 18.93 & 19.18 \\
\hline $\begin{array}{l}\text { Return on } \\
\text { Assets } \\
\text { Including } \\
\text { Revaluations }\end{array}$ & 79.59 & 94.52 & 145.86 & 169.24 & 201.42 & 324.38 & 344.44 & 470.19 & 545.46 & 127.52 & 152.20 \\
\hline $\begin{array}{l}\text { Capital } \\
\text { Adequacy } \\
\text { Ratio (CAR) }\end{array}$ & 11.12 & 11.66 & 12.16 & 11.41 & 13.08 & 13.60 & 15.69 & 17.44 & 16.22 & 16.52 & 16.80 \\
\hline $\begin{array}{l}\text { Credit } \\
\text { Deposit Ratio }\end{array}$ & 46.39 & 55.89 & 64.87 & 65.79 & 66.08 & 65.28 & 66.64 & 72.44 & 76.02 & 78.06 & 80.14 \\
\hline
\end{tabular}


Table 5 below gives the outcome of the paired t-test utilized to assess the bank's performance.

Table 5. Outcome HDFC

\begin{tabular}{|c|c|c|c|c|c|}
\hline Parameters & Merger & Mean & Std. Dev. & $\mathrm{t}$-value & Sig. \\
\hline \multirow{2}{*}{ Dividend Per Share } & Pre & 4.700 & 1.605 & \multirow{2}{*}{-1.836} & \multirow{2}{*}{0.140} \\
\hline & Post & 9.660 & 4.960 & & \\
\hline \multirow{2}{*}{ Net Profit Margin } & Pre & 16.052 & 1.586 & \multirow{2}{*}{-0.400} & \multirow{2}{*}{0.709} \\
\hline & Post & 16.786 & 3.621 & & \\
\hline \multirow{2}{*}{$\begin{array}{l}\text { Return on Assets } \\
\text { Including Revaluations }\end{array}$} & Pre & 138.126 & 50.897 & \multirow{2}{*}{-1.923} & \multirow{2}{*}{0.127} \\
\hline & Post & 327.962 & 186.330 & & \\
\hline \multirow{2}{*}{$\begin{array}{l}\text { Capital Adequacy } \\
\text { Ratio (CAR) } \\
\end{array}$} & Pre & 11.886 & 0.769 & \multirow{2}{*}{-12.632} & \multirow{2}{*}{0.000} \\
\hline & Post & 16.534 & 0.652 & & \\
\hline \multirow{2}{*}{ Credit Deposit Ratio } & Pre & 59.804 & 8.604 & \multirow{2}{*}{-9.124} & \multirow{2}{*}{0.001} \\
\hline & Post & 74.660 & 5.308 & & \\
\hline
\end{tabular}

Though the mean of Dividend Per Share (DPS) increased from 4.7 to 9.66 , the change was not significant, as indicated by an at-value of -1.836 and a significance value of 0.14 . Hence the null hypothesis $\mathrm{H}_{0}$ was not rejected for DPS. There was no major change in the Net
Profit Margin as shown by an at-value of -0.4 and a significance value of 0.709 (as this is greater than 0.05); hence the zero premise $\mathrm{H}_{0}$ was not discarded. Similarly, there was no noteworthy change in Return on Assets (including revaluations) as indicated by a t-value of -1.923 and the significance value of 0.127 . Hence, the zero premises H0 were not rejected. The Capital Adequacy Ratio (CAR) went up from 11.886 to 16.534 . The change was significant, as shown by a t-value of -12.632 and a significance value of 0.00 . The change in Credit Deposit Ratio was also significant, as shown by a t-value of -9.124 and a significance value of 0.001 , hence the null hypothesis $\mathrm{H}_{0}$ was rejected.

\subsection{ICICI Bank}

Table 6 under gives the key financial variables of the ICICI before and following the consolidation.

Table 6. Variables ICICI

\begin{tabular}{|l|c|c|c|c|c|c|c|c|c|c|c|}
\hline \multicolumn{1}{|c|}{ Parameters } & \multicolumn{5}{|c|}{ Pre Merger Years } & $\begin{array}{l}\text { Year of } \\
\text { Merger }\end{array}$ & \multicolumn{5}{c|}{ Post Merger Years } \\
\hline & 2005 & 2006 & 2007 & 2008 & 2009 & 2010 & 2011 & 2012 & 2013 & 2014 & 2015 \\
\hline Dividend Per Share & 8.50 & 8.50 & 10.00 & 11.00 & 11.00 & 12.00 & 14.00 & 16.50 & 20.00 & 23.00 & 5.00 \\
\hline Net Profit Margin & 16.93 & 14.49 & 10.92 & 10.53 & 9.82 & 12.29 & 19.83 & 19.27 & 20.77 & 22.20 & 22.76 \\
\hline $\begin{array}{l}\text { Return on Assets } \\
\text { Including } \\
\text { Revaluations }\end{array}$ & 170.35 & 249.55 & 270.37 & 417.64 & 444.94 & 463.01 & 479.45 & 524.43 & 578.65 & 634.60 & 138.72 \\
\hline $\begin{array}{l}\text { Capital Adequacy } \\
\text { Ratio (CAR) }\end{array}$ & 11.78 & 13.35 & 11.69 & 13.97 & 15.53 & 19.41 & 19.54 & 18.52 & 18.74 & 17.70 & 17.02 \\
\hline $\begin{array}{l}\text { Credit Deposit } \\
\text { Ratio }\end{array}$ & 89.17 & 87.59 & 83.83 & 84.99 & 91.44 & 90.04 & 90.45 & 97.71 & 99.25 & 100.71 & 104.72 \\
\hline
\end{tabular}


Table 7 shows the outcome of the paired t-test utilized to assess the bank's rendition.

Table 7. Outcome ICICI

\begin{tabular}{|c|c|c|c|c|c|}
\hline Parameters & Merger & Mean & $\begin{array}{l}\text { Std. } \\
\text { Dev. }\end{array}$ & $t$-value & Sig. \\
\hline \multirow{2}{*}{$\begin{array}{l}\text { Dividend Per } \\
\text { Share }\end{array}$} & & & & \multirow{2}{*}{-1.865} & \multirow{2}{*}{0.136} \\
\hline & & & & & \\
\hline \multirow{2}{*}{ Net Profit Margin } & & & 3.047 & \multirow{2}{*}{-4.302} & \multirow{2}{*}{0.013} \\
\hline & Post & 20.9 & 1.496 & & \\
\hline \multirow{2}{*}{$\begin{array}{l}\text { Return on Assets } \\
\text { Including } \\
\text { Revaluations } \\
\end{array}$} & & & & \multirow[b]{2}{*}{-1.362} & \multirow[b]{2}{*}{0.245} \\
\hline & Post & 471.170 & 194.737 & & \\
\hline \multirow{2}{*}{$\begin{array}{l}\text { Capital Adequacy } \\
\text { Ratio (CAR) }\end{array}$} & Pre & 13.264 & 1.606 & \multirow{2}{*}{-4.440} & \multirow{2}{*}{0.011} \\
\hline & Post & & 0.972 & & \\
\hline \multirow{2}{*}{$\begin{array}{l}\text { Credit Deposit } \\
\text { Ratio }\end{array}$} & Pre & 87.404 & 3.084 & \multirow{2}{*}{-4.188} & \multirow{2}{*}{0.014} \\
\hline & Post & 98.568 & 5.233 & & \\
\hline
\end{tabular}

Although the mean Dividend per Share increased before and after the merger, the change was not noteworthy. As shown by a t-value of -1.865 and significance value of 0.136 , the zero premises $\mathrm{H}_{0}$ was not rejected. The Net Profit Margin increased from 12.538 to 20.966 , which was significant as shown by a t-value of -4.302 and a significance value of 0.013 . Hence the null hypothesis $\mathrm{H}_{0}$ was rejected. Though the Return on Assets (Including Revaluations) increased, the change was not significant, as shown by a t-value of -1.362 and a significance value of 0.245 . The Capital Adequacy Ratio (CAR) increased from 13.264 to 18.304 , as indicated by a $\mathrm{t}$-value of -4.44 and a significance value of 0.011 . Credit Deposit Ratio also increased from 87.404 to 98.568 , as shown by a t-value of -4.188 and a significance value of 0.014 .

\subsection{Kotak Mahindra Bank}

Table 8 under gives the key financial variables of the Kotak Mahindra before and following the consolidation.

Table 8. Variables Kotak

\begin{tabular}{|l|c|c|c|c|c|c|c|c|c|c|c|}
\hline \multicolumn{1}{|c|}{ Parameters } & \multicolumn{9}{|c|}{ Pre Merger Years } & $\begin{array}{l}\text { Year of } \\
\text { Merger }\end{array}$ & \multicolumn{5}{c|}{ Post Merger Years } \\
\hline & 2009 & 2010 & 2011 & 2012 & 2013 & 2014 & 2015 & 2016 & 2017 & 2018 & 2019 \\
\hline & 0.75 & 0.85 & 0.50 & 0.60 & 0.70 & 0.80 & 0.90 & 0.50 & 0.60 & 0.70 & 0.80 \\
\hline Dividend Per Share & 8.46 & 15.34 & 19.52 & 17.55 & 16.91 & 17.13 & 19.19 & 12.75 & 19.27 & 20.68 & 20.32 \\
\hline Net Profit Margin & 112.98 & 130.40 & 92.23 & 107.28 & 126.53 & 159.35 & 183.09 & 130.61 & 150.01 & 196.69 & 222.13 \\
\hline $\begin{array}{l}\text { Return on Assets } \\
\text { Including Revaluations }\end{array}$ & 20.01 & 18.35 & 19.92 & 17.52 & 16.05 & 18.83 & 17.17 & 16.34 & 16.77 & 18.22 & 17.45 \\
\hline $\begin{array}{l}\text { Capital Adequacy } \\
\text { Ratio (CAR) }\end{array}$ & 100.34 & 94.61 & 94.27 & 100.90 & 97.75 & 92.18 & 88.99 & 86.57 & 86.04 & 87.35 & 89.70 \\
\hline Credit Deposit Ratio & & & & & & & & & & \\
\hline
\end{tabular}


Table 9 gives the outcome of the paired t-test that was utilized to assess the bank's rendition.

Table 9. Outcome Kotak

\begin{tabular}{|c|c|c|c|c|c|}
\hline Parameters & Merger & Mean & Std. Dev. & $t$-value & Sig. \\
\hline \multirow{2}{*}{ Dividend Per Share } & Pre & 0.680 & 0.135 & \multirow{2}{*}{-0.215} & \multirow{2}{*}{0.840} \\
\hline & Post & 0.700 & 0.158 & & \\
\hline \multirow{2}{*}{ Net Profit Margin } & Pre & 15.556 & 4.240 & \multirow{2}{*}{-1.280} & \multirow{2}{*}{0.270} \\
\hline & Post & 18.442 & 3.247 & & \\
\hline \multirow{2}{*}{$\begin{array}{l}\text { Return on Assets } \\
\text { Including } \\
\text { Revaluations }\end{array}$} & Pre & 113.884 & 15.379 & \multirow[b]{2}{*}{-3.684} & \multirow[b]{2}{*}{0.021} \\
\hline & Post & 176.506 & 36.540 & & \\
\hline \multirow{2}{*}{$\begin{array}{l}\text { Capital Adequacy } \\
\text { Ratio (CAR) }\end{array}$} & Pre & 18.370 & 1.673 & \multirow{2}{*}{1.261} & \multirow{2}{*}{0.276} \\
\hline & Post & 17.190 & 0.712 & & \\
\hline \multirow{2}{*}{$\begin{array}{l}\text { Credit Deposit } \\
\text { Ratio }\end{array}$} & Pre & 97.574 & 1.386 & \multirow{2}{*}{8.791} & \multirow{2}{*}{0.001} \\
\hline & Post & 87.730 & 0.701 & & \\
\hline
\end{tabular}

The Dividend per Share (DPS) change was not significant, as indicated by a t-value of -0.215 and a significance value of 0.840 . Hence, the null hypothesis $\mathrm{H}_{0}$ was not rejected. The increase in the average of NPM was not noteworthy, as shown by a t-value of -1.28 and a significance value of 0.27 . Hence the $\mathrm{H}_{0}$ was not rejected. Return on Assets (including Revaluations) increased from 113.88 to 176.5 as shown by a t-value of -3.684 and a significance value of 0.021 , it was rejected. There was no significant change in the Capital Adequacy Ratio (CAR), as shown by a t-value of 1.261 and a significance value of 0.276. The Credit Deposit Ratio reduced from 98.57 to 87.73 , as shown by a $t$-value of 8.791 and a significance value of 0.001 ; hence, the null hypothesis $\mathrm{H}_{0}$ was rejected [15].

The table below summarizes the results for the t-test for each and every bank.

Table 10. Results Summary

\begin{tabular}{|c|c|c|c|c|}
\hline Parameter & IOB & HDFC & ICICI & Kotak \\
\hline $\begin{array}{c}\text { Dividend Per } \\
\text { Share }\end{array}$ & increase & $\begin{array}{c}\text { no } \\
\text { change }\end{array}$ & $\begin{array}{c}\text { no } \\
\text { change }\end{array}$ & $\begin{array}{c}\text { no } \\
\text { change }\end{array}$ \\
\hline Net Profit Margin & $\begin{array}{c}\text { no } \\
\text { change }\end{array}$ & $\begin{array}{c}\text { no } \\
\text { change }\end{array}$ & increase & $\begin{array}{c}\text { no } \\
\text { change }\end{array}$ \\
\hline $\begin{array}{c}\text { Return on Assets } \\
\text { Including } \\
\text { Revaluations }\end{array}$ & increase & $\begin{array}{c}\text { no } \\
\text { change }\end{array}$ & $\begin{array}{c}\text { no } \\
\text { change }\end{array}$ & increase \\
\hline $\begin{array}{c}\text { Capital Adequacy } \\
\text { Ratio (CAR) }\end{array}$ & increase & increase & increase & $\begin{array}{c}\text { no } \\
\text { change }\end{array}$ \\
\hline $\begin{array}{c}\text { Credit Deposit } \\
\text { Ratio }\end{array}$ & increase & increase & increase & decrease \\
\hline
\end{tabular}

\section{Discussions}

A decrease in Dividend per Share (DPS) may indicate that the organization may be in poor financial conditions. Hence an investor would be tempted to sell his/her stake in the organization if there is a DPS decrease. Out of the four banks selected for this study, only Indian Overseas Bank showed an improvement in the Dividend per Share
(DPS). There was no statistically significant DPS change after the merger for the remaining banks, HDFC, ICICI, and Kotak Mahindra.

NPM is one of the most crucial parameters that can be used to assess the organization's financial well-being. Out of the four banks selected for this study, only ICICI Bank showed a statistically significant improvement in the NPM after the consolidation. There had not been a statistically noteworthy change in the Net Profit Margin for the rest of the banks, Indian Overseas Bank, HDFC, and Kotak Mahindra, after the consolidation.

ROA indicates the profits that an organization can make in comparison to its aggregate assets. Investors get information about the effectiveness of the firm in turning the finances it invests into aggregate income. The greater ROA is preferable, as the firm makes greater money on fewer investments. Out of the four banks selected for this study, there was a significant increase in ROA for the IOB and the Kotak Mahindra Bank. For HDFC and ICICI, the change in ROA was not statistically significant.

A bank with greater CAR is highly likely to handle its financial issues and is considered safe. The aim is to make sure that banks have adequate reserve capital to absorb a certain number of losses until they are at risk of being insolvent. Out of the four banks selected for this study, there was a significant increase in Capital Adequacy Ratio (CAR) for Indian Overseas Bank, HDFC and ICICI, after the merger. For Kotak Mahindra, the change in CAR after the merger was not significant.

A very low Credit Deposit Ratio suggests that banks are not utilizing their resources to the fullest. If the value reaches above a specific point, it implies a burden on its assets. Credit Deposit Ratio gives the earliest sign of the fitness of the bank. If the ratio's value is increasing, it could be a troubling sign as in addition to signaling burden on its assets, and it could also indicate capital sufficiency issues, compelling banks to increase their capital. A Credit Deposit Ratio of more than seventy percent shows a burden on assets as banks must put cash on one side to maintain a 4.5 percent cash reserve ratio and a twenty-three percent statutory liquidity ratio. Out of the four banks selected for this study, Credit Deposit Ratio increased for Indian Overseas Bank, HDFC, and ICICI and decreased for Kotak Mahindra. Hence the Credit Deposit Ratio only improved for Kotak Mahindra Bank.

\section{Conclusions}

For Indian Overseas Bank, DPS, ROA, and Capital Adequacy Ratio (CAR) improved. There was no change in NPM, but the Credit Deposit Ratio worsened. Hence for Indian Overseas Bank, three financial parameters improved out of 5 after the merger. For HDFC bank, there was no change in Dividend Per Share (DPS), Net Profit 
Margin and Return on Assets, and an improvement in Capital Adequacy Ratio but degradation in Credit Deposit Ratio. Hence only one financial parameter improved for HDFC after the merger. For ICICI, there was no change in Dividend per Share (DPS) and no change in ROA. NPM and Capital Adequacy Ratio improved, but the Credit Deposit Ratio worsened. Hence two parameters improved for ICICI after the merger. For Kotak Mahindra, there was no change in Dividend Per Share and Capital Adequacy Ratio but an improvement in Return on Assets and in Credit Deposit Ratio. Hence two financial parameters improved for Kotak Mahindra Bank after the merger. Hence on average, two financial parameters out of five improved for each bank after the merger.

Dividend per Share (DPS) improved for only one out of four banks. Similarly, Net Profit Margin also improved for only one out of four banks. Return on Assets improved for two out of four banks. CAR improved for three out of four banks. The Credit Deposit Ratio also only improved for one out of four banks. Hence, it can be said conclusively that CAR is the one parameter that improved after the merger. The same cannot be said conclusively for all the other parameters. Thus, we cannot conclusively say that the merger of the banks improved the financial performance of banks.

\section{Limitations and Recommendations}

The banks were only analyzed based on Dividends per Share (DPS), NPM, ROA, CAR, and Credit Deposit Ratio. The study could include other important indicators such as GPM, Operating Profit Margin, ROCE, ROE, Debt Equity Ratio, EPS, Current Ratio, Quick Ratio, Non-performing Asset (NPA) ratio, Provision Coverage Ratio, Loan to Asset Ratio, YOA, YOI, Profit gained by each Employee and Business that the organization gets for each employee, etc., that could give further insight into assessing the financial health of a bank before and following the merger.

This study includes a sample of four mergers, namely BHOB into IOB, Centurion Bank of Punjab into HDFC Bank, BOR into ICICI Bank, and ING Vysya Bank into Kotak Mahindra Bank. The paper can also look into the major mergers post-liberalization such as Nedungadi Bank into PNB in 2003, South Gujarat Local Area Bank into BOB in the year 2004, Global Trust Bank into OBC in the year 2004, United Western Bank into IDBI Ltd. in the year 2006, Nainital Bank into Bank of Baroda in 2006, Ganesh Bank of Kurundwad into Federal Bank in 2006 and Lord Krishna Bank into CBOP in 2006, which can be extended to include other recent bank mergers such as the consolidation of SBI with its five associates (State Bank of Patiala, Mysore, Travancore, Bikaner and Jaipur, and Hyderabad) and also with the Bhartiya Mahila Bank (BMB) in 2017, and the mergers announced in 2019 such as Bank of Baroda with Dena Bank and Vijaya Bank, Indian Bank with Allahabad Bank, Union Bank of India with Andhra Bank and Corporation Bank, Canara Bank with Syndicate Bank and last but not the least Punjab National Bank with Oriental Bank of Commerce and United Bank of India. Data across all the financial parameters can be collected before and after the merger to decide whether the consolidation improved the financial health of the bank and increased its market share or not.

The study in this paper was conducted on the data of financial parameters before and after the merger. This study does not include the qualitative parameters such as quality of Human resources, perception of the bank, accessibility of the bank, etc., before and after the merger. Hence, it is recommended to include these parameters to examine the consolidation's advantages in a qualitative sense. Some off-balance-sheet signals, such as securitization, commitments, lines-of-credit, etc., can also be looked upon to gauge the rendition post the coalescence.

Stock Price movements can also be assessed before and after the merger to check if the financial health of the bank ameliorated or not. The same data can be collected from the Bombay Stock Exchange (BSE) and the National Stock Exchange (NSE). There are two ways to check that. The first way would be to collect the closing stock prices 15 days prior and 15 days after the bank's consolidation or acquisition declaration, which would explain whether there is a correlation between the immediate gains or losses and the merger or the acquisition announcement. The second way would be to assess the stock price movements monthly or daily for a year or two before and after the merger or acquisition has been completed, which can also give us an idea of whether there was a significant change in the stock price before or after the merger or not.

This work aimed at finding whether the managerial decision of consolidation was worth it or not by taking a different set of financial indicators compared to the previous works such, etc., which is the unique aspect of this work. We concluded from this work that some financial parameters improve for the acquirer bank as seen in the previous work and some other works. This study concluded that CAR improved in all the consolidations taken for this work, which is an important finding that can help take the managerial decision of going with the consolidation or the takeover, even though the stock prices do not go up as per the findings of data. In general, the acquirer bank's financial well-being can be ameliorated through consolidation. This consolidation is a boon for the acquired bank due to its state of distress.

These days government of our country has made the consolidation or even the acquisition process of banks as a course of action to aid the distressed bank instead of identifying or treating the bad symptoms. Instead, the government plans and strategizes the methodology to identify and treat these bad symptoms such as NPAs. 
Through a consolidation or an acquisition, the distressed banks' bad symptoms are transferred to the acquirer or the bidder bank. These acquirer banks get better reach and clientele in return. However, the bad symptoms remain untreated.

\section{Acknowledgments}

Conflict of Interest: There is no conflict of interest among the authors

Funding: Self-funded

Ethical approval: Not applicable

\section{REFERENCES}

[1] N. Tamragundi, D., \& S, D. (2016). Impact of mergers on Indian Banking Sector: A comparative study of Public and Private Sector merged Banks. Acme Intellects International Journal of Research in Management, Social Sciences \& Technology, 1-18.

[2] Babu, M. R. (2019). Research on Profitability and Liquidity Position of Banks With Reference to Pre and Post-Merger. International Journal of Recent Technology and Engineering (IJRTE), 253-261.

[3] KP, D. V., \& Patti, S. (2016). FINANCIAL PERFORMANCE ANALYSIS OF PRE AND POST MERGER IN BANKING SECTOR: A STUDY WITH REFERENCE TO ICICI BANK LTD. International Journal of Management (IJM), 240-249.

[4] Khan, A. A. (2011). Merger and Acquisitions (M\&As) in the Indian Banking Sector in Post Liberalization Regime. International Journal of Contemporary Business Studies, 31-45.

[5] Mall, P., \& Gupta, K. (2019). IMPACT OF MERGER ANNOUNCEMENTS ON STOCK RETURNS OF ACQUIRING FIRMS: EVIDENCE FROM INDIA. Journal of Commerce \& Accounting Research, 46-53.
[6] Mathur, A., K. Vinitha, R. Shubham, \& K. Gowtham. (2018). Effect of SBI Bank Merger on Education Loan, a Comparative Study Using Big Data Analytics. International Journal of Engineering \& Technology, 452-455.

[7] Mondal, G. C., Pal, D. M., \& Ray, D. S. (2016). Merger and Its Effect on Performance of Indian Public Sector Bank: A Case Study on Merger of Nedungadi Bank and Punjab National Bank. International Journal of African and Asian Studies, 54-65.

[8] Patel, R. (2014). Pre-Merger and Post-Merger Financial \& Stock Return Analysis: A Study with reference to selected Indian Banks. Asian Journal of Research in Banking and Finance, 1-9.

[9] Patel, R. (2018). Pre \& Post-Merger Financial Performance: An Indian Perspective. Journal of Central Banking Theory and Practice, 181-200.

[10] R, N. K., VJ, V., \& Reddy, M. B. (2019). A Study on the Impact of Pre and Post Bank Merger Announcement on Stock Price Movements. International Journal of Research and Analytical Reviews (IJRAR), 995-1001.

[11] Rajamani, M., \& Dr. P. R. Ramakrishnan. (2015). A Study on Impact of Merger of Centurion Bank of Punjab on the Financial Performance of HDFC Bank. IOSR Journal of Humanities and Social Science (IOSR-JHSS), 28-31.

[12] S, D. D. (2017). Effect of Mergers on Efficiency of the Banks: A Study of Selected Merged Banks in India. IOSR Journal of Business and Management (IOSR-JBM), 47-57.

[13] S, D. D. (2018). Evaluation of Physical Performance of Merged Banks: A Study of Selected Merged Public Sector Banks in India. International Journal of Research in Management, Economics, and Commerce, 22-29.

[14] Sai, V. R., \& Sultana, D. S. (2013). FINANCIAL PERFORMANCE ANALYSIS IN BANKING SECTOR A PRE \& POST MERGER PERSPECTIVE. International Monthly Refereed Journal of Research In Management \& Technology, 56-66.

[15] Samontaray, 1. D., \& Choudhary, M. K. (2013). Merger \& Acquisition in Indian Banking Industry: An Event Study Approach. Australian Journal of Basic and Applied Sciences, 252-262. 